\title{
Social Imaginaries in Debate
}

\author{
Suzi Adams, Paul Blokker, Natalie J. Doyle, \\ John W.M. Krummel and Jeremy C.A. Smith
}

\begin{abstract}
Investigations into social imaginaries have burgeoned in recent years. From 'the capitalist imaginary' to the 'democratic imaginary', from the 'ecological imaginary' to 'the global imaginary' - and beyond - the social imaginaries field has expanded across disciplines and beyond the academy. The recent debates on social imaginaries and potential new imaginaries reveal a recognisable field and paradigm-in-the-making. We argue that Castoriadis, Ricoeur, and Taylor have articulated the most important theoretical frameworks for understanding social imaginaries, although the field as a whole remains heterogeneous. We further argue that the notion of social imaginaries draws on the modern understanding of the imagination as authentically creative (as opposed to imitative). We contend that an elaboration of social imaginaries involves a significant, qualitative shift in the understanding of societies as collectively and politically-(auto)instituted formations that are irreducible to inter-subjectivity or systemic logics. After marking out the contours of the field and recounting a philosophical history of the imagination (including deliberations on the reproductive and creative imaginations, as well as consideration of contemporary Japanese contributions), the essay turns to debates on social imaginaries in more concrete contexts, specifically political-economic imaginaries, the ecological imaginary, multiple modernities and their intercivilisational encounters. The social imaginaries field imparts powerful messages for the human sciences and wider publics. In particular, social imaginaries hold significant implications for ontological, phenomenological and philosophical anthropological questions; for the cultural, social, and political horizons of contemporary worlds; and for ecological and economic phenomena (including their manifest crises). The essay concludes with the argument that social imaginaries as a paradigm-in-the-making offers valuable means by which movements towards social change can be elucidated as well providing an open horizon for the critiques of existing social practices.
\end{abstract}

Key Words: Social imaginaries - Cornelius Castoriadis - Paul Ricoeur - Charles Taylor - political imaginaries - creative imagination - economic imaginaries ecological imaginaries - multiple modernities - civilisational analysis 


\section{Introduction}

Our approach to the emergent field of social imaginaries involves two significant moves. The first is to recognise that debates on social imaginaries have progressed to the point where it is possible to distinguish an overall 'field' that address central problematics of social and political life. The vitality of the field can be attributed in some part to the variety of intellectual sources informing it, as well as to the richness of those sources. We understand the works of Cornelius Castoriadis, Paul Ricoeur, and Charles Taylor to be the cornerstones of the field. This very diversity of approaches becomes a basis for further reflection and debate on the theoretical articulation of social imaginaries; indeed, the social imaginaries field has been enriched through its very heterogeneity. Subsequently, it has become possible to discuss ecological, global or cosmopolitan and other emergent imaginaries - as, for example, the participants in the roundtable discussion on modern social imaginaries in the current issue do (Calhoun et al. 2015).

The second move is to argue that the emergence of social imaginaries as a 'paradigm-in-the-making', to borrow a term from Johann P. Arnason, marks a qualitative shift in the way that social, cultural and political phenomena are understood and problematised. Investigations into social imaginaries redefine overarching ontological, epistemological and anthropological problematics, on the one hand, as well as concrete political and social questions, on the other. The key interpretative frameworks encountered within the social imaginaries field provide rich, non-reductive understandings of the multi-faceted aspects of contemporary worlds. Explorations of social imaginaries comprise inquiries not only into horizons of cultural meaning that fundamentally shape each society (and civilisational complex), but also into their further articulation as instituted (and instituting) cultural projects of power and social doing. Most approaches in the field presuppose an understanding of society as a political institution, which is formed - and forms itself - in historical constellations, on the one hand, and through encounters with other cultures and civilisational worlds, on the other.

Furthermore, explorations of social imaginaries are centrally concerned with at least ten interrelated trends. First, social imaginaries emphasise the properly social aspect of the imagination instead of reducing it to a faculty of the individual mind. This is the difference between 'the imaginary' and 'the imagination' (concomitantly, this can be extended to the difference between 'rationality' and 'reason'). This shift can be understood as central to the ongoing, albeit incomplete, hermeneutical turn in the human sciences. Second, social imaginaries grasp the imagination as authentically creative rather than as merely reproductive or imitative. This, third, involves a shift from a one-sided focus on 'reason' as the central tenet (or promise) of modernity, and instead posits modernity as a field of tensions co-instituted by cultural 
varieties of imaginaries and rationalities. This is not to say, fourth, that reason is rejected; indeed, the more sophisticated theoretical approaches to social imaginaries also do justice to varieties of rationality and public reason. In this vein, the practice of logon didonai remains central to all forms of thoughtful doing and philosophical elucidation. Fifth, modernity's constitutive tension between reason and imagination is best elucidated as competing versions of 'worldhood' offered by Enlightenment and Romantic cultural currents. Extending this further, sixth, the question of the varieties of worldhood - and/ or world alienation - in modernity (and multiple modernities) becomes a problematic in its own right. The problematic of the world has been a long standing theme of phenomenology, and is an emergent theme in recent sociopolitical thought. In taking up the phenomenological question of the world, approaches to social imaginaries open onto interrogations of the ontological and anthropological pre-conditions of human modes of being in-the-world. Seventh, social imaginaries focus on collectively instituted - and instituting - forms of meaning. Because meaning is social (and not reducible to intersubjectivity), this involves an elucidation of the properly trans-subjective aspect of socio-cultural activity - in the form of meaning, action, and power - as the precondition for inter-subjective modes of being-in-the-world. The trans-subjective aspect of society is what Castoriadis terms the anonymous collective, and is matched to an understanding of the world as an overarching, trans-objective horizon. In this way, the main approaches to social imaginaries radicalise the critique of the subject/object division that was central to early phenomenological analyses by extending it to the properly societal dimension of the human condition. Eighth, social imaginaries - as cultural articulations of the world - elucidate cultures (in the anthropological not aesthetic sense) as open rather than closed. In this way, a richer understanding of human societies' encounter not only with other cultures and civilisations, but also with the world can be developed. The human encounter with the world requires it to be put into meaning (as world formation). Such approaches posit a minimum commonality to the human condition writ large but emphasise its historical diversity as distinct civilizational articulations of the world. This allows for the human condition to be understood as a unity in a plurality, whilst the accent on the twofold aspect of meaning (its 'sociality' and 'worldhood') necessitates a rethinking of philosophical anthropological notions of culture beyond socio-centric reductionism (c.f. Arnason 1993; Adams 2011a). In this way, social imaginaries lends itself to analyses of the human condition in its intercultural and inter-civilisational varieties, on the one hand, and to comparative civilisational analyses of formations and encounters, on the other. Ninth, as social imaginaries takes society to be a political institution, it emphasises the situated nature and collective forms of social interaction, in particular regarding democratic politics and the capitalist market economy, whilst, in a related vein, tenth, it does not reduce analyses of social formations and projects of 
power to normative considerations alone. This is closely related to the necessity of strengthening debates on political (understood in Castoriadis's strong sense of 'la politique), and not just ethical responses to our current world situation (including crises of the environment, democracy and the capitalist market imaginary). Thus, in problematising the human condition in modernity (and indeed the many modernities of our times) in light of the above inter-related trends, interpretations of social imaginaries constitute a powerful field of debate.

We begin this essay by reconstructing the most important theoretical articulations of social imaginaries, and then contextualising them within the broader field. The modern understanding of the imagination as authentically creative is one of the pre-conditions for contemporary elucidations of social imaginaries; in this context, we then take measure of the philosophical history of the imagination. Following on from that, we concretise our discussion by investigating key approaches to political, democratic, economic and ecological imaginaries. We conclude with an outline of the common ground between the fields of social imaginaries and civilisational analysis.

\section{Theorising Social Imaginaries}

The social imaginaries field is very heterogeneous. There are a number of possible reasons for this: there is a range of intellectual sources and currents that inform debates on social imaginaries, but specific perspectives tend to be advanced without real acknowledgment of - or engagement with - this diversity, and the concomitant field of tensions that it engenders. These intellectual sources range from the sociological tradition, beginning with Durkheim's (1976 [1912]) notion of collective representations (as distinct from the collective conscience) and including Benedict Anderson's (1991 [1983]) neo-Durkheimian approach to imagined communities, to (especially Francophone) phenomenological currents of thought, articulated, for example, in Sartre's (1962, 1966 [1944]) distinction between the imaginary and the imagination, and in Merleau-Ponty's hesitations about the mode of being of the imaginary in his later work, to approaches influenced by hermeneutic-phenomenological problematics, such as the three thinkers under consideration here: Ricoeur's (1986) work on the social imaginary of ideology and utopia, Taylor's (2004) post-Merleau-Pontian understanding of the background horizon of meaning, and Castoriadis's (1987 [1975]) critical engagement with Merleau-Pontian and to a lesser extent, Sartrean - approaches to the (social) imaginary. Lacan's legacy for social imaginaries is mixed but cannot be ignored. He brought the term 'imaginary' into common academic parlance (as part of his tripartite understanding of psychical structures: the symbolic/the imaginary/the real), but his articulation of the imaginary can also be seen as a psychoanalytic response to Sartre's earlier elucidation of the imaginary and the imagination 
(Lacan 1977). Some thinkers who are associated with the social imaginaries field, however, especially those who work more explicitly in relation to political imaginaries (such as Claude Lefort or Ernesto Laclau and Chantal Mouffe) fruitfully engage with aspects of his thought. Here it is instructive to note the importance of Freud for Ricoeur and Castoriadis's respective understandings of the creative imagination in relation to dreams and meaning, but strictly speaking the psychical domain is quite separate from the region of social imaginaries, and thus is of lesser relevance in the present context. Finally, historical interpretations of ideology have been linked to the imaginary (and more broadly, the symbolic) and this has been influential for the social imaginaries field, for example, in Ricoeur (1986) and Lefort's (1986) thought.

This essay identifies the three most significant articulations of social imaginaries to be those by Cornelius Castoriadis (1987), Paul Ricoeur (1986), and Charles Taylor (2004), respectively. Castoriadis had been writing on social imaginary significations since the mid-1950s; his 'first attempt' ${ }^{\text {' }}$ at systematically elucidating social imaginaries occurred in the mid-1960s (although his preferred term is social imaginary significations); and his mature elucidation of social imaginary significations - and his concomitant turn to ontology - began from the early 1970s. These two attempts were published in his magnum opus, L'Institution imaginaire de la société in 1975. In the same year, Ricoeur presented two series of seminars at Chicago University. The first was his now famous lectures on ideology and utopia (1986), which comprise the two poles of the cultural imagination; the other seminar series was on the philosophy of the imagination, more generally. ${ }^{2}$ Ricoeur used the term social imaginary unsystematically; he more often employed concepts, such as 'ideology', 'utopia', or 'cultural imagination' to refer to these 'practical fictions'. The actual term social imaginaries was popularised almost three decades later with the publication of Charles Taylor's Modern Social Imaginaries (2002, 2004); here Taylor was influenced by Branislow Baczko's earlier work (1984; c.f. Abbey 2006). Each of the above mentioned three thinkers anchored his account of social imaginaries in understandings of the modern imagination as both creative and social, although the contrasts between them cannot be overstated (we return to the philosophical question of the imagination in the next section below).

Put simply, theories of social imaginaries elucidate the ways in which cultural configurations of meaning creatively configure the human encounter with - and formation (as articulation and doing) of - the world, on the one hand, and, articulate their centrality for the emergence, formation and reproduction of social institutions and practices, that is, of social change and social continuity, on the other. To paraphrase Castoriadis: society itself is an imaginary institution. A central innovation of the social imaginaries field has been to connect the formation of meaning to the creative imagination (or more specifically: to the imaginary element). It is important to note, however, that social imaginaries are irreducible to meaning alone. The three main 
approaches to social imaginaries identified herein variously incorporate other dimensions of the human condition as well, such as power, action/social doing, and/ or institutions.

The emphasis on the imagination is in sharp contrast to the more conventional focus placed on the import of reason/rationality for modernity. Indeed, the tension between reason and imagination is central to the institution of cultural modernity (and understandings of the human condition within it). One of the key aspects of the modern imagination is that it is understood to be fundamentally and authentically creative (or productive) - not just reproductive or imitative (we return to a more detailed discussion of the history of the imagination below). More specifically, social imaginaries highlight the imaginary element of the human condition instead of the imagination as a faculty of the singular human being. As Arnason has argued, the still partial shift to the imaginary is to be understood as an ongoing but incomplete hermeneutical shift from the imagination to the imaginary and, concomitantly, from reason to rationality. It is worth quoting him in full on this point:

To shift our notions of reason and imagination in this direction would be to relate them more closely to the constitution and appropriation of meaning to patterns of world-interpretation, and to the space that is thus opened up for interpretative conflicts. More specifically, the hermeneutical transformation referred to above would entail a revision of dominant preconceptions: if we still tend to think of reason and imagination primarily as abilities or competences - reason as the ability to ground and justify to find and give reasons imagination as the ability to envisage and fantasise to grasp and generate images - we may have to learn to think of them as dimension or elements (in the sense that Bachelard, Merleau-Ponty and Castoriadis have given to the term 'element') i.e. as aspects or component of culture more precisely of the cultural articulations of the world (Arnason 1994, p. 155).

Clearly Arnason is working towards a cultural hermeneutics but one that is grafted onto phenomenology; specifically, a post-transcendental phenomenology that takes the problematic of the world horizon in its trans-subjective/ trans-objective interlacing, as a question in its own right.

Despite the richness of their accounts - and the rapid proliferation of the social imaginaries field, more broadly - scant attention has been given to critical comparisons of Castoriadis, Ricoeur and Taylor's perspectives on social imaginaries. There are very few exceptions: Graham Ward (2005) has given an overview of their respective approaches to social imaginaries in relation to cultural change and religious practice; Johann Michel (2013) has recently brought Castoriadis and Ricoeur into dialogue on the question of social imaginaries and institutions; Suzi Adams (2011) has discussed the respective approaches of Ricoeur and Castoriadis to creation and interpretation 
(2011b); Karl Smith (2010) has compared Castoriadis and Taylor's accounts of subjectivity and the self in modernity, but his focus was not social imaginaries per se; Meili Steele (2003) has critically discussed Taylor and Ricoeur's approaches to language and narrative, but, again, the question of social imaginaries was not the central concern. On a more general level, Claudia Strauss's (2006) rather one sided account of 'the imaginary' includes a discussion of Castoriadis and Taylor but her interest in psychological aspects precludes a constructive engagement with key tenants of the social imaginaries field. John Grant (2014) has recently criticised the 'imaginaries' field for neglecting the properly political dimension, but he focuses only on three North American accounts, reduces Castoriadis to a footnote, and excludes mention of Ricoeur altogether, which is perplexing given Ricoeur and Castoriadis's central grappling with various aspects of socio-political imaginaries with which Grant concerns himself (we return to the question of political imaginaries, below). There is, however, a very interesting, albeit indirect, encounter on the question of the social imaginary to be found in eminent Ricoeur scholar, Richard Kearney's interview with Charles Taylor (Kearney and Taylor 2007). There is moreover a record of a direct encounter between Ricoeur and Castoriadis in 1982 on Radio France (Culture). ${ }^{3}$ Whilst this discussion focussed more on the question of the imagination as creative/ productive/ interpretative, it also touches on issues concerning social imaginaries.Each of the three theorists under consideration clearly emphasises the importance of the imaginary dimension for the human condition (in modernity), but they do so in different ways. We shift our attention now to consider each in turn.

Castoriadis's mature work elucidates social imaginary significations in ontological terms. The social-historical as the radical imaginary of instituting society, creates a world of meaning - as, in, and through social imaginary significations - ex nihilo, through and as which we encounter/institute 'reality. This forms the background horizon for the configuration of key institutions of each society. He writes: 'The institution of society is in each case the institution of a magma of social imaginary significations, which we can and must call a world of significations' (Castoriadis 1987, p. 359; emphasis in original). Social imaginary significations 'create a proper world for the society considered - in fact, they are this world' (1994, p. 152, emphasis in original; see also Castoriadis's contribution to this issue: Castoriadis 2015). Castoriadis's shift to ontology in the early 1970s was in order to elucidate the mode of being underlying collective autonomy (particularly in the form of direct democracy) as self-creating, and, simultaneously, as a critique of theories of society that reduce it to frameworks of determinacy, such as systemic logics. After his critique of Marx, Castoriadis reactivated ancient Greek images of direct democracy - that is, a society that understands itself to be self-instituting and as such does not attribute its form, laws, culture and customs to an extrasocial source, such as God, and that recognises the need to institute collective 
self-limitation - in his rethinking of the project of autonomy. On his account, the ancient Greeks created - brought into being - democracy as a new form (eidos) of society. This has weighty ontological implications: human societies create ontological form. Castoriadis's ontology is thus, as Dick Howard (1988) has termed it, a political ontology, properly understood. If autonomy was Castoriadis's enduring political project (he identified as a revolutionary long after his critique of Marx and the disbanding of Socialisme ou Barbarie), then the issue of human creation was his most enduring philosophical problematic. The previously noted modern tension between imagination and reason plays out on the ontological level for Castoriadis. His ontology of the radical imaginary as instituting society forms a key part of his critique of the presuppositions of traditional western philosophy, specifically the understanding of being as determinacy and identitary logic (or as he called it ensemblistic-identitary logic). In this he is part of a broad current of thought that critiques the metaphysics of presence, along with thinkers such as Nietzsche, Heidegger, and Derrida.

Central to understanding Castoriadis's approach to social imaginary significations is his connection between time and creation, on the one hand, and time as social-historical time, on the other. In brief this refers to his rejection of time as quantitative and measurable (the 'spatialisation of time', as he calls it) and the development of a qualitative notion of time as the social-historical auto-creation of ontological otherness, as the emergence of new forms - such as the ancient Greek creation of democracy - and the rejection of 'abstract time' as devoid of concrete content. Thus time is the creation of new ontological forms (eide) in and as history. These overarching forms are then open to a plurality of further articulations, such as ancient Greek democracy in, for example, its Spartan, Athenian, and Corinthian variants, or modern capitalism in its English, German or Japanese varieties.

Castoriadis's approach to social imaginary significations plays out not only on the ontological level but also on the cultural hermeneutic level: concrete articulations of the world are activated through their articulation in - and as - key social institutions. Thus, for Castoriadis, modernity is a dual institution comprising the central social imaginary significations of autonomy and the infinite pursuit of (pseudo) rational mastery. These social imaginary significations underpin the institutions - and their interwoven social practices - of, for example, democracy, on the one hand, and bureaucracy and capitalism, on the other. Here the main point is that Castoriadis understands these social practices/ institutions as articulations, or concrete manifestations, of broader imaginary significations that fundamentally shape the modern human condition in-the-world (See Arnason's essay in this issue: Arnason 2015).

Like Castoriadis, Ricoeur draws on the specifically modern understanding of the productive imagination to articulate the social imaginary - specifically in its open dialectic with the reproductive imagination, which he identifies as the core of ideology and utopia (1986). The ideological imagination 
reproduces an image that society has of itself (usually a founding image/ myth), whilst the utopian imagination produces alternative images of society that put ideological images into question. For Ricoeur, the social imaginary is a product of the cultural imagination in its ideological and utopian variants (these roughly correspond to Castoriadis's understanding of instituted society and instituting society) and these overlap in his thought with the social and political imagination. Ricoeur understands the social imaginary as 'the touchstone of the practical function of the imagination' (1994, p. 118), in contrast to its theoretical mode (although the utopian imagination is situated more at the intersection of theory and practice). In the lectures, Ricoeur undertakes a rich hermeneutic of the ideological and utopian poles of the imagination (1986). As the emphasis is on practical life, Ricoeur focuses on a hermeneutical phenomenology of action both as symbolic and as anchored in symbolic contexts. He writes: 'Ideology and utopia have ultimately to do with the character of human action as being mediated, structured and integrated by symbolic systems' (1976, p. 512). In addition, and unlike Castoriadis, Ricoeur explicitly includes an analysis of power in his understanding of the cultural imagination. ${ }^{4}$ Although Ricoeur had developed his own account of action in relation to symbolic systems, he enriched it further through an intensive engagement with Clifford Geertz's (1973) notion of 'symbolic action' and 'symbolic systems', coupled with Mannheim's (1954 [1929]) insight of ideology and utopia's 'non-congruence' with social reality. Ricoeur wants to delineate both the polarity between each term, as well as the 'functional' and 'pathological' or 'distorted' modalities that both ideology and utopia can take. In the case of ideology, this can mean the concealment of hidden interests; for utopia it means eschewing the necessity of action in favour of escapism into the 'empty space of 'nowhere" (1976, p. 22). Ricoeur goes on to argue that ideological 'distortion' of social reality is only possible if social reality is always already symbolised (and symbolising). In its functional sense, ideology reproduces society's image of itself; it maintains collective identity and cohesion; its role is to legitimate and integrate society's representation of itself. Where the ideological imagination is conservative, the utopian imagination is subversive. In its positive aspect, utopia problematises the instituted order of society, and offers a counter-world characterised by alternative configurations of power in its search for 'the possible' as opposed to the 'given'.

Ricoeur's focus on human action is in line with his overall philosophical anthropology that takes the 'capable self' as its basis. However, the capable self acts within - and draws on and interprets - socio-cultural contexts, and it is here that Ricoeur's version of the imaginary element as trans-subjective emerges. Ricoeur's approach to the imaginary element is anchored in his theory of linguistic meaning, and occurs at the intersection of its symbolic, metaphoric and narrative versions. Unlike Castoriadis, Ricoeur does not make a formal distinction between symbolic and imaginary elements of meaning: 
for him, the social imaginary is 'an ensemble of symbolic discourses' that can 'function as a rupture or a reaffirmation' (1991a, p. 475), that is the activity of the socio-cultural imagination as it pertains to the practical domain; the imaginary element is a given society's 'hidden mytho-poetic nucleus' (1991b, p. 483).

Unlike Castoriadis and Ricoeur, Charles Taylor's approach to social imaginaries was not developed solo but in loose collaboration with the Centre for Transcultural Studies, including, for example, Craig Calhoun, Dilip Gaonkar, Benjamin Lee, and Michael Warner (see their collective contribution to this issue: Calhoun et al. 2015). The associated journal, Public Culture, published a special issue on New Imaginaries (Lee \& Gaonkar 2002), to which Taylor contributed the essay 'Modern Social Imaginaries' (2002). He reworked the essay into what is arguably the best known text in the social imaginaries field tout court - Modern Social Imaginaries (2004) — and then developed the framework further still in sections of A Secular Age (2007). Articulated as part of an overall approach to multiple modernities, Taylor's account, like the debates on multiple modernities and civilisational analysis spearheaded by S.N. Eisenstadt (2003) and Arnason (2003), argues for a cultural approach to modernity and its multiplication (Taylor 1999).Modern Social Imaginaries does not specifically deal with multiple modernities however; rather, it seeks to articulate a self-understanding of the modern western social imaginary from which inter-civilisational variants can then be further elaborated in an open dialectic of self- and other-understanding (we return to this thematic in the final section of this essay).

Taylor does not explicitly engage with Castoriadis or Ricoeur's earlier accounts of social imaginaries; instead his key intellectual sources include Benedict Anderson's (1991) notion of 'imagined communities', and, as mentioned above, Bronislaw Baczko’s (1984) approach to social imaginaries. Taylor's version reworks the tension of reason and imagination in modernity by maintaining that he was not providing a theory of social imaginaries; the social imaginary is 'not a set of ideas; rather it is what enables, through making sense of, the practices of society' $(2004$, p. 2). Key aspects here to note include the centrality of meaning-making to social imaginaries, coupled with already instituted forms of social doing (rather than openings towards rupture and social change), and the emphasis on the collective dimension of society (rather than the on the self, as was most notably the case in Sources of the Self (1989), although he has always rejected individualist and atomist social ontologies). His long interest in the phenomenological themes of practical know-how and implicit knowledge influence his understanding of social imaginaries. Although Taylor traces the advent of social imaginaries through key philosophical-theoretical articulations by such thinkers as Locke, Grotius, Rousseau and Tocqueville, his aim is rather to assert their common bedrock in everyday life 
as well as what underlies an (admittedly fragile) sense of unity dispersed across geographical space (in the vein of Anderson's 'imagined communities').

Finally, Taylor elucidates three spheres of social practices that institute modernity and which draw on the horizon of the social imaginary for meaning and legitimation: First, popular sovereignty and collective self-governance, which points to the prior existence of society to the polity, and the importance of common agency; second, economic practices of, in particular, the market economy, which is depicted as private and without a sense of common agency; and, third, the public sphere which sits external to the polity but internal to society and highlights the answerability of the former to the latter.

Although Castoriadis elucidates social imaginary significations at the ontological level, his hermeneutic of modernity - and the political project of autonomy, more broadly - brings his account of social imaginaries into practical life in line with Ricoeur and Taylor's approach. Both Ricoeur and Castoriadis place considerable emphasis on the creative/productive imagination elucidated by Kant and the Frühromantiker, and seek to rework its implications, whereas this is of less concern for Taylor. Both Castoriadis and Ricoeur are interested in instituted/ reproductive forms of the social imaginary, as well as the rupturing/instituting aspect, but where Castoriadis is most interested to elucidate the radical instituting imaginary, Ricoeur, in his seminars on social imaginaries (1986), devotes fourteen lectures to ideology and only three to utopia (but it is relevant to note that he meditates on some of the utopian aspects of the imagination via the poetic imagination which he carries out in other works). Both Taylor and Ricoeur have an explicit interest in hermeneutics and narrative, and both tend to equate social imaginaries with a sense of the symbolic, whereas for Castoriadis the symbolic is essential for the imaginary element, but the imaginary forms the precondition of symbolic networks. Although, Castoriadis's approach to social imaginary significations arguably incorporates a hermeneutical dimension (Arnason 2015; Adams 2011), he himself explicitly rejects this aspect. This informs his disagreement with Ricoeur regarding the productive imagination versus the creative imagination, and Ricoeur's insistence on the hermeneutical aspect of production (and more broadly, the open dialectic between reproductive and productive aspects of the imagination). ${ }^{5}$ The hermeneutical dimension also points to the question of the imagination as a key aspect of philosophical modernity's 'field of tensions' (Arnason 1991), to which we now turn.

\section{History of the Imagination}

The social imaginary as a philosophical concept is related to the imagination itself both in terms of its meaning and its historical context. For its historical inception we can look back to Aristotle's discovery of the imagination (phantasia). The imagination here as the requirement for thought is passive 
(pathos), functioning in relation to the power of sensation (Aristotle 1986, Book 3). As a consequence the Greek tradition has taken the imagination to be fundamentally imitative or reproductive of sense perception. But because the sensible object's activity upon the imagination is mediated by the senses, the imagination escapes its full constraint to become active and creative to an extent. This makes it potentially deviant, a source of error as we find later in René Descartes's devaluation of the imagination. Yet more recent thinkers have noted something about that creativity of the imagination that never really won its proper place within the Western philosophical tradition, an implicit poiesis although Aristotle himself never makes the connection between phantasia and poiesis.

That creative or productive function of the imagination becomes pronounced in modern philosophy with Immanuel Kant. Creativity at least in its epistemic significance - and eventually in its ontological significance for the Romantic tradition and the German idealists - becomes a function of the human mind and no longer confined to divinity. ${ }^{6}$ In Kant, who jumpstarts this move, the imagination (Einbildungskraft) is an a priori faculty of intuition that is productive (produktive) or active (tätiges) (1965/1993, p. A118, A120), rather than passive. ${ }^{7}$ But the centrality of its creativity Kant underscores in the first edition of the Kritik der reinen Vernuft is subsequently reduced and submerged under the dictates of reason in the second edition.

In the first edition of the Critique, Kant describes the imagination as one of the original sources of all experience that itself cannot 'be derived from any other faculty of the mind' (1965/1993, p. A94). He speaks of its a priori transcendental synthesis as antecedent to all experience and 'conditioning the very possibility of all experience' (1965/1993, p. A101), allowing for the empirical application of the categories of the understanding to the sense impressions we receive (1965/1993, p. A125). In this way it brings sensibility and understanding, intuitions and concepts, together. On this basis he makes the implicit suggestion that the imagination is actually the 'common, but to us unknown, root' of sensibility and understanding (1965/1993, p. B29, p. $\mathrm{B} 863)$. As the power of synthesis in general, the imagination as such is 'a blind but indispensable function of the human soul' necessary for cognition (Kant 1965/1993, p. A78/B103).

Another definition of the imagination Kant provides is that it is 'the faculty to represent in intuition an object even without its presence' (1965/1993, p. B151). This can refer to the reproductive sense of the imagination when one has an image of what one has seen. But it can also refer to its productive aspect if what is produced is something one has not perceived. Despite its placement as the mediator between the receptivity of sense impressions and the spontaneity of conceptual understanding, there is an active-creative component here belonging to the side of spontaneity. ${ }^{8}$ The process of the schematism in the second edition underscores this a priori formative feature of the 
imagination as 'an art concealed in the depths of the soul' (Kant 1965/1993, p. B180). The schematism provides rules for producing images for concepts. With the concept of 'dog', or 'triangle', for example, the schematism delineates its figure in a general manner without delimiting it to the determinate image a particular experience (of a dog or a triangle) might present (Kant $1965 / 1993$, p. B180). Thereby it represents that which is not itself present, not an image - the schema. ${ }^{9}$ Hannah Arendt (1992 [1982], pp. 80, 84-85), more recently, has noticed how an analogous sort of creativity can be found in the construction of exemplary rules in the historical or political domains, ${ }^{10}$ and Ricoeur (1994, pp. 112-123; c.f. 1986) has interpreted this more generally as metaphorical attribution that gives image to meaning.

In the end, though, Kant retreats from that primacy of the imagination as a creative power of synthesis, which may entail uncertainties, and relegates it to a more secondary status, subordinate to epistemic concerns. This becomes evident in the second edition of the first Critique, as has been noted by some." The potentially unbounded creativity of the imagination - along with its historical or temporal contingency as later noted by Heidegger and Castoriadis - become tightly fettered to the laws reason lays down a priori for the sake of true cognition.

But what was circumscribed within cognitive bounds in the first Critique is given a somewhat looser rein in the Kritik der Urteilskraft (Kant 1952) within the realm of aesthetics. Kant gives the imagination, in its 'free activity' or 'free play' (Kant 1952, pp. 122-123, 212), an artistic role beyond the epistemic domain in the productive capacity of the genius to create the unseen and thus reorder reality (Kant 1952: $\$ \$ 46-47,49$ ). Exceeding the bounds of conceptuality, the aesthetic product of genius cannot be fully translated into language or symbols and induces in its audience an experience that likewise exceeds linguistic and conceptual boundaries.

Kant problematises that unconstrained creative activity of the imagination further with the introduction of the sublime. In the sublime one experiences awe and anxiety before the powers of nature or humanity that transcend the bounds of any purposiveness. The imagination's creative dimension here is loosened from its cognitive function and expanded in pursuit of reason's idea of infinity, but which, moving beyond reasonable limits, moves to inevitably exceed any sense of purpose that reason assigns to things - whether our own humanity or to nature (Kant 1952, $\$ \$ 23-28$; c.f. Rundell 1994, pp. 103104). The sublime points to that creative unboundedness of the imagination perceived externally while genius is the bearer of that creativity within to give it aesthetic expression. Both the sublime and genius underscore the creativity of the imagination irreducible to the terms of reason and understanding in the cognitive or theoretical sphere, and problematises its communicability. On the other hand Kant does attempt to fetter that creativity with his notion of taste as socialised for 'universal approval' under the faculty of judgment (Kant 
1952, $\$ 50$; c.f. Rundell 1994 , pp. 106,116 n.66), which in turn, however, opens the question of historicity and contingency underlying communal taste and with which the imagination engages in hermeneutical dialogue.

After Kant, the German Romantics and Idealists take up the theme of the creative imagination. The productivity Kant discovered begins to replace that of divine creation to fully flower in Schelling, for whom the imagination is an organ of nature, expressing its creativity through our unconscious, ultimately transcending individual subjectivity and its finitude (Roberts 1994, p. 173). A little later Heidegger, by contrast, reads Kantian imagination in the opposite direction centring on human finitude.

Heidegger focuses upon the imagination's formative capacity (Vermögen des Bildes) (Heidegger 1977, p. 278; 1990, p. 89; 1991, p. 128; 1997, p. 189) as indicated in the German einbilden, literally, 'to in-form', 'to form in(to)'. Radicalising the sense of our being-situated in the world, he ontologises the imagination beyond its epistemic functions. His Kant reading of the 1920s, Kant und das Problem der Metaphysik of 1929 but also Phänomenologische Interpretation von Kants Kritik der reinen Vernunft of 1927-28, takes Kant's imagination that brings together sensibility and intelligibility (Heidegger 1990, pp. 103, 121; 1991, pp. 153, 177), especially as indicated in its time-formation and the schematism, to be derivative of - in some sense even identical with - the temporality (Zeitlichkeit) of human existence that constitutes the horizon of comportment analysed in Sein und Zeit in the sense that our cognitive concerns are ultimately and tacitly guided by our existential concerns, our concern for being in the face of death. The latter allows for and guides our projection of a world-Bild (world-picture or image) as the contextual horizon or 'pre-form/view' (Vor-Bild) in light of which things can manifest for us and be meaningful (Heidegger 1969, pp. 88-89; 1990, p. 99; 1991, pp. 144-45; 1998, pp. 122-123). Einbildungskraft in its Bildung of a Bild is thus broadened as ontologically constitutive of our being-in-the-world. But its creativity in the formation (bilden) of the horizon is inextricably linked to - even derivative of - human finitude, lived temporality as the ultimate horizon of mortal existence.

In his later (post-1930) works Heidegger either demotes the imagination as a representational faculty belonging, as an epochal feature, to modernity; or furthers its ontological broadening, radicalising it in terms of the clearing event (Lichtung, Ereignis) or poiesis of being that opens the world and human existence. ${ }^{12}$ Common to both is a further downplaying of the spontaneity of human subjectivity. Finitude and receptivity in human existence become even more pronounced. In Beiträge zur Philosophie of 1936-38, for example, the imagination is no longer a transcendental faculty of the soul, '.. but rather event [Ereignis] itself... as the occurrence of the clearing [Lichtung] itself' (Heidegger 1994, p. GA 65: 312; 1999, p. 219). Here the imagination as the unfolding of being is released from confinement to the human subject, 
instead understood as the process of ontological formation in the configurings of unconcealing-concealing. Die Zeit des Weltbildes (1938), on the other hand, historicises the imagination as a station in the history of the forgetfulness of being' (Heidegger 2003). Parallel to the modern self-deification of consciousness, the world as a totality of beings becomes represented through the imagination - Einbildungskraft - in a picture or image, Bild, thus objectified by man, in the modern age (Heidegger 2002, pp. 69-70, 76; 2003, pp. 92-93). And during the 1950s, Heidegger speaks of imagings or imaginings in the plural - Ein-Bildungen ('in-formations') - as the 'poietic' occurrence of being that brings to human beings the measure of dwelling and to which poetry responds (c.f. Sallis 1990). 'Poetry' in its deeper ontological significance as poiesis speaks in 'images' or 'forms' (Bilder) - the provision of an ontological measure - and thus involves 'imaginings' (Ein-Bildungen) of sorts (Heidegger 1971, pp. 225-226; 2000, pp. 204-205). The imagination as ontological or 'poetic'-dichterische Einbildungskraft (Heidegger 1985, p. 17; 1971, p. 197) sounds from a source beyond human subjectivity. Hence the 'free' spontaneity of the imagination in Heidegger's last phase ultimately comes to refer to the anonymous opening of being wherein the human being- $(t)$ here is thrown, opened, and grounded.

The notion of a creative imagination has developed in other disparate ways throughout the twentieth century in different corners of the world. Castoriadis credits Sigmund Freud's analysis of the unconscious and its psychic creativity as 'an important but unacknowledged rediscovery of the imagination' (Castoriadis, 1987, p. 281; c.f. 1994, p.136). The American pragmatist philosopher John Dewey conceived the imagination (e.g., in A Common Faith, 1962 [1934]) as a faculty that projects ideals and values, offering possibilities and motivations for thought and action, and that provides a picture of the whole, serving to secure a sense of community and communion with the universe.

The power of the imagination as creative and constitutive of human social existence has been recognised in East Asia as well. In World War Two Japan, Miki Kiyoshi in his Kösōryoku no ronri (Logic of the Imagination) for example took the imagination's creation of images out of emotion, passion, or impulse - pathos - to culminate externally in the production - poiesis - of 'formed images' (keizō) (from the Greek eidos and German Bild) (Miki, 1967a, p. 46; 1967b, p. 473). As examples he mentions myth, technology, and the institutions (seido) of society, all of which undergo change through the history of human action. The imagination as such expresses the human impulse to act and produce by inventing, constructing, and altering reality (Miki, 1967a, pp. 15, 49; c.f. Miki, 1967b, p. 477). And in post-war Japan, Nakamura Yūjirō, who looks to Miki as a predecessor, discusses the same sort of social collective creativity that forms the world in terms of 'common sense' (kyötsü kankaku). Taking off from Aristotle's koinè aisthèsis and Vico's sensus communis, and referring 
to Kant's Gemeinsinn from the third Critique, Nakamura in Kyötsükankakuron (On Common Sense, 1983) develops an understanding of 'common sense' as the way in which the various senses are integrated at the point where the senses and reason meet. As such it is in phase with the imagination and is constitutive of a communal horizon of meaning, making judgment and communication possible. Nakamura associates common sense with the creativity of the imagination in Miki, and in this association we may find possible resonances with contemporary notions of the social imaginary.

Meanwhile, roughly contemporary to Nakamura, a major thinker in the contemporary West who has thematised the creative imagination in its ontological significance, while developing the concept of the social imaginary, is Cornelius Castoriadis. More generally, Castoriadis utilises the notion of the 'creative imagination' as an umbrella term for the more specific radical imagination of the psyche, on the one hand, and the radical imaginary of the social-historical (as social imaginary significations) on the other. Taking off from Kant's understanding as well as Aristotle's, and building on Freud's theory of the unconscious, Castoriadis defines the imagination as 'the power to make be that which realiter is not' (Castoriadis 1994, p. 139; emphasis in original; c.f. 1997, pp. 213ff, 246ff), meaning what is not given whether in perception or previously constituted thought. The radical imagination (and the radical imaginary) - taking radical in its root sense, radix, as originary - is a creative force that creates ex nihilo (Castoriadis 2007, p. 73). This capacity distinguishes, for example, the human psyche from the animal psyche and is founded on the flux of representational spontaneity at the root of our psyche that escapes subordination to any predetermined end. One of Castoriadis's many contributions to the discussion of the imagination is to show that it is a 'spontaneous, creative, afunctional force' $(2007$, p. 205). What the creative imagination creates are images but which are forms - forms of being, whether language, institutions, art, and so on (1994, p. 140; 2007, p. 73). In its afunctional spontaneity, the creative imagination needs to be tamed but the taming is never fully accomplished and it can never be brought under complete control. Human activities 'introduce infinitesimal alterations' in the imaginary significations thus instituted $(2007$, p. 109). The forms imagination creates are never complete but allow for alteration and novelty. Thus like Heidegger in his reading of the Kantian imagination, Castoriadis emphasises temporality as well (c.f. 1987, pp. 372-373). But if Heidegger focuses on the finitude revealed in the receptivity of the imagination, Castoriadis focuses on the autonomy or freedom revealed in the spontaneous flux of the radical imagination that on the one hand precludes reduction to functionality and escapes predetermination, but on the other hand permits creativity, novelty, and ruptures.

In the various above-mentioned analyses, starting with Kant, the depth of the imagination that begins to open up in its creative significance for the 
human experience leads to the temporality, historicity, and contingency of the transcendental and the a priori. In some cases, it has also opened up onto articulations of the social imagination, which is more properly understood as the social imaginary (as distinct from the imagination as a faculty of the mind). The particular tension engendered by modern understandings of the imagination and reason - and more particularly in this context, of imaginaries and rationalities - plays out further in the socio-political domain, to which we now turn.

\section{Social Imaginaries and Modernity}

\section{Political-Economic Imaginaries}

The notion of political imaginary draws attention to the historical and contextual nature of political phenomena and to their sui generis nature under conditions of modernity. It points to their fundamental embeddedness in social life as well as their roots in imaginary configurations of meaning. The notion of political imaginary draws attention to the fact that political meaning is essentially social and not reducible to individual meaning-giving. Studies that draw on this notion thus demarcate themselves from both Marxism and Liberalism which they critique for failing to appreciate the fact that societies are always acts of political creation, an act which becomes self-reflexive in democracy.

The work of two thinkers has been particularly seminal with regard to the theorisation of political imaginaries: that of Claude Lefort and Cornelius Castoriadis, both of whom emphasised the historical mode of social life that underpins modern democracy in its understanding of and relation to what they define as the political (Breckman 2013; Doyle 2003, 2011; Thompson 1982). Castoriadis and Lefort make a crucial key distinction between the political, as an attribute of all societies and politics. The latter is an innovation explicitly linked to modernity for Lefort, whereas for Castoriadis the flourishing of politics in modernity consists of a reactivation of the ancient Greek discovery of politics as collective autonomy. (Lefort's distinction is also central to the writings of Marcel Gauchet on the tensions of the contemporary democratic imaginary as his essay in this issue illustrates; Gauchet 2015). Both Castoriadis and Lefort stress that plurality and historical variance are at the heart of the democratic condition. They differ, however, in how they define the political and by extension on how they interpret modern politics (we return to this below). For Castoriadis, the political is a dimension of any society's self-institution which takes the form of explicit power, of forms of authority that are 'capable of formulating sanctionable injunctions' (1991, p. 156). For Lefort, drawing on Merleau-Ponty's phenomenology, the notion incorporates that of symbolic representation: power is always power of representation and 
the political is actually what allows society to institute itself by providing it with a 'form' that allows it to become aware of itself. Lefort (1988) expresses this idea through a rather elliptic play on words when he says that a society's 'mise en sens' (structuring of meaning, in others words the creation of its imaginary identity) is both a 'mise en forme' (the creation of a specific form given to human coexistence, the creation of a 'regime') and a 'mise en scène' (staging, in the sense of theatrical representation). For Lefort, to understand a society, is then to understand it in terms of its own definition of power, as the specific symbolical response by human beings, given in different historical contexts, to the problem of their coexistence.

The political is thus at the heart of a society's very being. Politics, on the other hand, concerns the relationship which a society entertains to the power structures it has established (Lefort 1988). Although all human societies display a political dimension, the political is not institutionalised in the same way, while politics manifests itself in different ways and in various arenas depending on historical and societal contexts (cf. Smith 2012). In Lefort's terms, modern politics - or policy - refers to explicit political activity or the struggle for public power in society, which takes on a specific guise in modern democracies. Politics as a delineated sphere or set of activities has been historically instituted as a result of a fundamental shift in the social imaginary of modern societies. Castoriadis's view, on the other hand, is more radical and normative in that politics for him only exists when it is self-reflexive, when it includes active societal engagement, and concerns the common good. ${ }^{13}$

These insights are important, in that politics is too often understood as a self-evident phenomenon, undergirded by self-explanatory, universalistic principles, such as representation, equality etc. (cf. Rosanvallon 2009). Lefort, in contrast, argues that the distinct modern understanding of politics is historically institutionalised, but has remained blind to its own historicity. This blindness was a result of the way ideology replaced religion in the definition of society's identity and erected transcendent principles supposedly emanating from the natural world itself (Lefort 1986). In contrast with the discourse of political 'science', which is concerned with the surface mechanics of politics, Lefort's approach establishes that the more general (and prior) political and historical constitution of modern democracy - its specificity as a political regime, the principles on which it is based, and the distinct meaning of the relegation of politics to a confined societal sub-sphere - ought to constitute the fundamental object of reflection. It draws attention to the obscured divisions in modern societies as well as to the tendency to leave the general principles of politics untouched by critical reflection:

The fact that something like politics should have been circumscribed within social life at a given time has in itself a political meaning, and a meaning which is not particular, but general. This even raises the question of the constitution of social space, of the form of society, of the essence of what was once termed 
the 'city'. The political is thus revealed, not in what we call political activity, but in the double movement whereby the mode of institution of society appears and is obscured. It appears in the sense that the process whereby society is ordered and unified across the divisions becomes visible. It is obscured in the sense that the locus of politics (the locus in which parties compete and in which a general agency of power takes shape and is reproduced) becomes defined as particular, while the principle that generates the overall configuration is concealed (Lefort 1988, p. 11).

This 'principle' which Lefort alludes to and which, as seen above, he defines as a process of symbolisation ultimately originates in the social imaginary. In this regard, it is useful to return to Castoriadis in that it is in his work we find more explicit reflections on the relation between the political and imagination, although his work is not without conceptual tensions in this regard (cf. Karagiannis and Wagner 2012). In Castoriadis's understanding of politics, that is, politics as the possibility of society to act upon itself, reflexive political engagement emerges only in two precise historical instances, in ancient Greece and in modernity. It is only in these historical contexts of autonomous societies (rather than the heteronomous ones that predominate in human history) that a more radical imaginary and connected forms of social doing are able to emerge in society and to inform the political. Such a radical imagination entails an explicit engagement with the uncertainty and indeterminate nature of human society, which resists closed views of the human world's reliance on an otherworldly dimension.

Thus, under circumstances of democracy, a special relation between politics and the imagination can be identified, which involves 'struggles over the collective outcome of imagination' (Karagiannis and Wagner 2012, p. 14). In a way similar to Lefort's insistence on the dangers of closure, whose radical reappearance in modern form he identified in totalitarianism (1986, pp. 273-291). Castoriadis's view is critical of (rationalistic) attempts to diminish the (radical) political imagination by means of an insistence on the institutionalisation of an ideal order or political arrangement framed by universalism. Such attempts are nowadays often based on notions of human and fundamental rights, the rule of law, and divisions of power. One of his key insights is that imagination is ultimately unpredictable and cannot be fully channelled or grasped a priori. Lefort equally emphasises this indeterminate nature of democracy, in which every aspect of society can ultimately be questioned, although he was less dismissive of the significance of modern liberalism in which he saw the creation of a new imaginary of power, which cannot be dissociated from democracy. Building on his analysis of totalitarianism as an attempt to deny social conflict and political indeterminacy by reintroducing a unitary representation of society fused with an egocrat (1986, pp. 292-306), Lefort defined the imaginary of modern democratic power as an empty space (lieu vide); that is, popular 
sovereignty exercised by people who never incarnate it but merely represent it for the limited time set by elections (Lefort 1988).

The political imaginary of democracy requires extensive reflection and exploration, but does not receive such attention in much of political philosophy and political science. In Castoriadis's and Lefort's engagement with the democratic imaginary, distinctive dimensions come to the fore that tend to be overlooked in rationalistic and institutionalist approaches to democracy. The latter promote a closure of reflection by pursuing the quest for an 'ideal' good order. The modern democratic imaginary is, however, ultimately grounded in an internal view of justification, or, in other words, the democratic order can only be justified by means of reference to society and social relations itself, not by reference to extra-societal markers such as religion or nature. This means, first, that democracy entails a highly uncertain and indeterminate political form, which is open to critique and re-imagination, and, second, that it is ultimately impossible to find a durable solution to the political question with which all human societies are confronted. There is, at its basis, an irreducible tension between the instituted reality of society and the world as an overarching horizon (which can only ever be partially grasped in, by, and as institutions). Castoriadis terms this the interplay between kosmos and chaos. Less explored by Castoriadis himself, but of great importance for the analysis of political imaginaries is the acknowledgment of agon or political struggle in which various political imaginaries are contested, on the one hand, and the changing nature of democratic societies over time, on the other. One upshot of such a view is that democratic societies are understood as less cohesive than much of sociological and political-theoretical work takes them to be, as well as being inherently conflictual and grounded in a variety of social meanings. This also means that such a view recognises how various political imaginaries may underpin distinctive types of democracy (cf. Blokker 2010; Eisenstadt 1999; Lamont and Thevenot 2000; Taylor 2002).

The necessity for an analysis of (shifting) political imaginaries in contemporary times is evident. In an age of intensified internationalisation and globalisation, as well as the fragmentation of nationally based political communities, the linkage between the democratic imaginary and a commitment to (collective) autonomy seems to have become less and less self-evident. Castoriadis already labelled contemporary 'advanced democracies' as 'liberal oligarchies' (Castoriadis 1991, p. 231). The imaginary signification of autonomy has lost its hold in contemporary democracies leading to a possible 'lack of political imagination' (Karagiannis and Wagner 2012, p. 26), and appears increasingly displaced by attempts to achieve some form of closure. This occurs through the promotion of imaginaries of technological or technocratic mastery (technocratic/elite rule), of cultural unity (populism), and/or depoliticised or 'natural' universal principles (human rights). 
The imaginary signification of collective autonomy has increasingly lost its purchase, and must be related to the affront of neo-liberalism as a radical form of capitalist modernity. This neo-liberal form of capitalism, as it has emerged from the 1970s onwards, can be linked to a radically individualised notion of autonomy and self-realisation (cf. Boltanski and Chiapello 2005), which in itself contributes to the depoliticisation of the public realm, not least in terms of social solidarity. The explicit posture of some form of interrelationship between political modernity in its democratic form and economic modernity in its capitalist form makes the contemporary predicament more intelligible: the decline of democracy is also a consequence of the emergence of the idea of radical market society and its radicalisation of individualism. But it equally strongly suggests a political basis of capitalism, that is, the idea that the economy is always in some way politically constituted (as Joerges et al. 2005 have it, we should understand the 'economy as a polity'). Regarding the dominance - and resilience - of contemporary neo-liberal capitalism, it is then possible to argue that there is both a relative lack of political imagination (in terms of the articulation of alternatives) and a closure of the economic imaginary in the form of depoliticisation, meaning the active denial of the need for a political, public discussion of the means and ends of the market economy (cf. Blokker 2014; Straume and Humphrey 2010).

\section{The Ecological Imaginary}

Neo-liberal capitalism as an instantiation of closure of the political imagination intensifies the unending pursuit of rational mastery, as Castoriadis characterised the social imaginary significations of capitalism. The dominance and resilience of contemporary neo-liberal capitalism has widely-recognised implications and dangers for the world's already-imperilled environments and there is significant opposition to the degree of destruction of the biosphere. For Castoriadis the counter-point of capitalism's quest for rational mastery is the project of autonomy. While he did not use the phrase 'ecological imaginary' it is possible to discern in his work an approach to such a demarcation of the limits of modernity and a reconceptualisation of the continuities and discontinuities of the human and non-human world. What is often taken as the other of the social - nature - is gravely at risk and there is an urgent need to interrogate the various imaginaries of nature in modernity as well as the images of nature that underpin current debates concerning the environment. Modernity has seen the realm of history invested with meaning, whilst concomitantly the kosmos has been stripped of its intrinsic significance. Modern forms of rationality and rationalisation, such as those embedded in the classical scientific worldview, have underscored the 'meaningless' of nature, whilst the expansion and intensification of the imaginary significations of capitalism have rendered the natural an endless 'quarry' of resources without cultural significance. That being said, even notions of nature as seemingly bare of 
meaning and reducible to rational knowledge alone (such as those at the core of scientistic and capitalistic imaginaries) still demonstrate a very particular and peculiar - configuration of meaning only possible through the emergence of the social-historical condition of modernity. Many of the current elaborations of modernity's core social imaginaries (see the above section on the field of social imaginaries) have generally downplayed - or ignored - the imaginary of 'nature' as a central signification for the modern human condition (unlike 'history' or 'freedom'). In these cases, nature is reduced to a background phenomenon, as it is not considered a purely generative (and we might add, human created) signification.

Castoriadis is a partial exception to this neglect. Examination of the shifts in his ontology and his philosophy of nature indicate an exploration of the ecological imaginary (Adams 2011, 2012). There are two inter-related parts to his thinking: his ontology in The Imaginary Institution of Society (1987) and ecological politics in relation to his project of autonomy. In The Imaginary Institution of Society, nature is cast as the 'first natural stratum' which is self-organising (but not self-creating). The first natural stratum encompasses physical and organic strata of nature. A perceptible shift in his thinking occurred after the initial publication (in French) of the The Imaginary Institution of Society in the late 1970s. Over the course of many years of participation in lively debates around biological being (and particularly in exchanges with the Chilean biologist Francisco Varela), Castoriadis developed a distinctive characterisation of the living being. He increasingly reconsidered the creative aspects of nature, and during the 1980s began to argue for all modes of being (both human and non-human) as self-creating. As part of this shift, he began to develop a polyregional ontology of modes of being for-itself which spanned the living being to social-historical being. Common to each of these modes of being was the capacity to ontologically create a proper world (Eigenwelt) (Castoriadis 1997, pp. 142-150). The living being is characterised by three capacities: 'the finality of self-preservation, self-centredness, and the construction of a world of one's own' (Castoriadis 1997, p. 143). Each kind of being for-itself exercises the three characteristics in ways that go beyond elementary sentience. Living beings are thus able to 'image' and 'relate' different elements of the environment as 'a world of one's own' thus creating a primary horizon of 'proto meaning' of existence (Castoriadis 1997, p. 148). In acts of representation of related elements different beings are creating (and not just assembling) worlds for themselves and all beings do this - notwithstanding the significant variations of existence marking different modes of being.

With this shift, Castoriadis elucidated 'a general ontology of creative emergence' (Adams, 2012, p. 319). It is important to stress that he did not collapse the specificity of human modes of being into nature; that is, he maintained the tension between nomos and physis at the political level, whilst extending his notion of self-creation as physis more generally at the ontological level to all 
regions and modes of being. If, as Castoriadis suggests, creative emergence is a shared ontological condition of all living beings then the degree of continuity between humanity and other species is greater than he had earlier reckoned. Yet the notion of nature elaborated in The Imaginary Institution of Society (1987) endured in Castoriadis's adherence to the project of autonomy which presupposed a specific form of creation instituted by human societies; that is, the capacity for autonomous self-determination (as nomos). Castoriadis's conclusions in his second philosophy of nature developed across the 1980s and 1990s therefore have further implications for his overall project. One sympathetic critic believes that 'he never reformulated the central themes of his philosophy in light of ecological thought' (Clark 2002, p. 74). This is a hasty judgment. The above account of his philosophy of nature shows a second phase in which he departed from more sociocentric perspectives to anthropologically situate humanity in the world. In connecting with what Adams calls 'a Romanticist imaginary of nature' (2011, pp. 137-144), Castoriadis places humanity in constant worldly engagement with nature. By implication, Castoriadis not only recuperates a Romantic vein of thought and representation but also develops a line of inquiry that could lead in different directions other than the project of autonomy.

This brief survey of Castoriadis's conception of nature and ecology would be incomplete, however, without a presentation of his more specific thinking on ecological politics and autonomy, which also emerged in the 1980s. In his 1981 publication on ecology and autonomy (crafted with Daniel CohnBendit) Castoriadis argues that ecology calls into question the social by problematising the creation of needs, questioning the neutrality of the Enlightenment's scientific imagination and illuminating the collective desire for conquest of non-human worlds within the capitalist imaginary. Yet, ecology also casts doubt over the conceptual apparatus of political economy by invoking 'the total position and relation between humanity and the world and, finally, the central and eternal question what is human life? What are we living for?' (1981, p. 14). By raising and addressing the 'primary questions' in a certain way, ecology was pre-figuring future of the project of autonomy in Castoriadis's optimistic estimation. Ecology's capacity to apprehend environmental crises as a problem of the social imaginary gives its questions and arguments a radicalism in the sense of going to the fundaments of the capitalist imaginary. His angle on the ethics of autonomy - as it might be known in another register - is vital in countering the hubris of the imaginary signification of rational mastery; that is capitalism's tendencies to endless growth. Ecological autonomy in his assessment is 'the question of the self-limitation of society' (1981, p. 19; emphasis added) in the most general sense. Specific currents of green politics do not in themselves necessarily produce the politics of self-limitation. But ecology tends to situate human life in the world. 'It isn't a love of nature; it's the need for self-limitation (which is true freedom) of human beings with 
respect to the planet on which they happen to exist by chance' (Castoriadis 2010, p. 203). Reconceiving the continuities and discontinuities of humanity on the basis of collective self-limitation would be a starting point for the reimagination of forms of sustainable worldly engagement with nature.

As mentioned above, Castoriadis's reconsideration of science and knowledge from the vantage-point of a philosophy of nature is consubstantial with the outgrowth of his interest in physis. But at the same time he does not abandon his overall emphasis on the imaginary of nomos. The latter remains a key discontinuity between human and other modes of being. Arguably his advances towards a far-reaching theorisation of the ecological imaginary founded on this particular and significant limit to his ontology. In addition, with his emphasis on a radical notion of time as creation, the problematics of space and place do not figure in his political thought, in general, and his philosophy of nature, in particular. Yet, as key phenomenologists have shown, phenomenology of experiences of place would seem to be vital to imaginaries of nature (Casey 1993; Malpas 1999; Sallis 2000; c.f. the essay by Nakamura Yujiro (2015) and the accompanying introduction by John Krummel (2015) in this issue). In this vein, a notion of place/space as qualitative and dynamic would be an important complement to Castoriadis's notion of qualitative time as creation of otherness (Nishida's notion of basho would be an important resource in this regard. c.f. Adams 2014; Krummel 2014). Re-thinking imaginaries of nature and potential ecologies also requires a reconsideration of capitalist modernity. Recognition of the close connection between capitalism and environmental devastation is of course obligatory. At the same time, complexities of modern capitalism can be further elucidated in terms of (a) inter-relationships with modern political figurations (as we argue in the section on political imaginaries) and (b) the sheer varieties of instantiation of the capitalist imaginary (Arnason 2001; Smith 2014a, 2014b; Straume and Humphrey 2010).

Notwithstanding this, Castoriadis goes further in relating social and ecological imaginaries than any other thinker in the field of social imaginaries (see also recent developments by Soper 2009, and Rundell 2012; c.f. Calhoun et al. 2015, in the present issue). On the other hand, Taylor's preliminary engagement with ecology in his early Philosophical Papers (1985) and his essay on Heidegger (1995) is not continued in Modern Social Imaginaries (2004). In this context cross-fertilisation with other fields can be a beneficial strategy. If the ecological imaginary is a newly charted frontier for the field of social imaginaries, then it is a fresh one also for civilisational analysis, as Arnason (2003, p. 218) has noted. Robust approaches in civilisational analysis would need to relate to the ontological aspects of the imaginaries of nature discussed above. At the same time, the sketches of the ecological imaginary we find in the field of social imaginaries could gain from an understanding of the manner in which civilisational constellations circumscribe the continuum of human and 
non-human worlds and shape the degrees and types of responsiveness to the contemporary crisis of environmental atrophy. While these specific connections cannot be detailed here, suggestion of a productive cross-fertilisation of this sort demands some elaboration of general articulations of the two fields of social imaginaries and civilisational analysis, to which we now turn.

\section{Multiple Modernities, Comparative Civilisations and Social Imaginaries}

Common ground between the fields of social imaginaries and the comparative analysis of civilisations has yet to be fully delineated and explored. Studies of civilisations have proliferated since the 1980s when S. N. Eisenstadt (1986) led renewed interest in questions of Axial civilisations emergent in Eurasia in the first millennium BCE. Karl Jaspers (1953 [1949]) famously theorised this period as the Axial Age. Comparative and historical sociologists joined histories in multidisciplinary projects that fostered debates about the emergence of reflexivity and complex creativity (Arnason, Eisenstadt and Wittrock 2005; Bellah and Joas 2012). Discussions of the difficult coalescence of civilisational patterns with definable ontological distinctions of different levels of reality - the 'transcendental' and 'mundane' in Eisenstadt's terms - alluded to social imaginary significations without explicitly invoking 'social imaginaries.' Principally, the imagination of a higher order of reality had ramifications for how economic, political, religious and cultural life were structured and reformed, according to advocates of Axial Age hypotheses. The Axial Age was debated as one in which civilisations capable of problematising and re-imagining the worldly order emerged (Taylor 2012). Ancient Greece has been an exemplar of Axial transformation from some points of view just as it was paradigmatic of creation and autonomy in Castoriadis's eyes. Beginning with the Homeric imagination, the Greeks were the first to question the given world, a conclusion separately reached by Eisenstadt and Castoriadis (Arnason 2012). Many of the disputes about Axial Age civilisations are unsettled, however, including the generation of varieties of reflexivity across different civilisations. Be that as it may, the quality and nature of the questions raised about this era of cultural and ontological differentiation and second order cognitive reflexivity relate to major changes in the modes of life. As it broached metatheoretical issues so innovatively, the Axial Age debate acted to refine civilisational analysis as a paradigm. Moreover, it marked the emerging paradigm with a defining feature: pluralism. Pluralism and metatheoretical reconstruction became defining features of civilisational analysis and featured in its most contentious claims.

Along with the retrieval of the Axial Age, civilisational analysis has debated the controversial proposition of multiple modernities, first developed by Eisenstadt (2000). The intention was clearly to guide civilisational analysis in a more deeply pluralistic and non-Eurocentric direction. 'Multiple modernities' 
is a kindred perspective of civilisational analysis that Eisenstadt and his collaborators developed along a long path out of modernisation sociology. They have not been alone in infusing the concept of modernity with an awareness of pluralities. Gaonkar theorised a notion of 'alternative modernities' (1999; 2001), Pieterse one of 'new modernities' (2012), Therborn 'entangled modernities' (2003), Arnason's 'multiplication of modernity' (2002), and Kaya 'later modernities' (2004) to mention only a few. If social theory is dense with attempts to reformulate the idea of modernity, Eisenstadt and his associates distinguish themselves by delimiting the cultural ontologies of multiple civilisations to arrive at a portrait of multiple modernities. Those cultural ontologies thereby set a conceptual limit to the number of modernities under analysis. For Eisenstadt cultural ontologies frame processes of cultural, political and economic institutionalisation.

Taylor and Arnason merit special consideration in the context of consideration of multiple modernities, civilisations and social imaginaries. Taylor sees the imaginary as background meaning enabling moderns to grasp society as objectified, as a set of processes, detached from any agential perspectives' (2004, p. 163). The connection with multiple modernities is latent in his elucidation of social imaginaries. On one hand, he analyses a distinct social imaginary which differentiates Western modernity. Western modernity imagines a collective order running through categories of sovereignty, democratic practices and a democratic public sphere, and market economies. The particularity of the West lies in, for instance, imagination of the economy as a system rather than a set of practices. Connections between particular social imaginaries and modernities are expressly made, even though Taylor does not invoke the phrase 'multiple modernities'. On the other hand, his feeling is that there are other modernities other than the West, which implicitly he leaves to others to spell out (Taylor 2004, pp. 195-196).

Arnason goes further in the comparative historical sociology of 'other' modernities through development of a theoretical perspective that reconfigures Castoriadis's elucidation of the social-historical as part of a civilisational framework (Arnason 2003, 2012). In effect he challenges the field of civilisational analysis to deepen its pluralism with understanding of the multiplication of modernity thereby invoking multiple imaginaries. In his post-transcendental phenomenological terms, if the social imaginary (in the singular) can be cast as a world, then the imaginary is also relative to different forms of interpretation, processes of state formation and regimes of accumulation, that is civilisational contexts of meaning, power and wealth. Arnason activates a cultural hermeneutic of modernity (and multiple modernities) by reconceiving civilisational forms as socio-cultural contexts of worldhood. Thus, crucially, modernity is not self-grounding but is rather grounded in relation to - and encounters with - a variety of 'others', including classical antiquity, intercultural others, inter-civilisational others, and intra-cultural constellations. The cultural 
hermeneutic of modernity is brought to bear in cases of highly creative civilisational constellations through exploration of how meaning and institutions of power and wealth are generated through encounters within and between civilisations. In instances of particularly intense and creative encounters forms of interpretation become highly active in processes of transformation. In his own comparative historical sociologies, Arnason examines how creative interpretations of traditions have informed formations of Soviet and Japanese modernities. In this regard, Arnason links post-transcendental phenomenology to historical sociology in order to deepen a pluralistic conceptualisation of civilisations. Arguably, however, the comparative analysis of civilisations has yet to fully assimilate the hermeneutical turn he has initiated.

With perspectives on civilisations, social imaginaries and modernities such as Taylor's and Arnason's, civilisational analysis has become a more open field. Other currents add to the range of viewpoints. Social theorists, historical sociologists, world historians and archaeologists are joined in the growing field of civilisational scholarship by comparativists in international relations and economic sociology (Hall and Jackson 2007; Katzenstein 2010). Interdisciplinary research carried out in this vein has thus far achieved much in exploring and debating the character of institutional and economic dimensions of past and present social formations. In particular development of longer histories of transformation across Eurasia has produced two telling results. First, it has brought attention to early modernities (explored along with multiple modernities) with findings that bring richer nuances to arguments that the trajectories of modernity had sixteenth century beginnings, rather than roots in the eighteenth century Enlightenment. Second, it has rightly created the impression of a higher level of connection, encounter and engagement between civilisations than previously reckoned. The longer historical view at work in civilisational analysis, however, also underscores the multidimensionality of social formations and the variety of modernities referred to above. Not only is more empirical and historical research needed; modification of the entire frame of civilisational analysis is an imperative, particularly in light of debates around social imaginaries.

There are therefore grounds for further elaboration and clarification, at the interstices of philosophy and social theory, of the central problems of civilisational analysis. Calls from outside the field for a stronger emphasis on experience as well as interpretation (Wagner, 2015) and for engagement with Critical Theory (Delanty 2010) suggest that the interpretive and critical energies of civilisational analysis could expand still further. Along with Jose Domingues's (2012) invocation of 'civilisational imaginaries of modernity' as the counter-weights of global modernity and new currents in international relations scholarship there is also evident potential for new versions of civilisational analysis after Eisenstadt and in wake of his focus on cultural ontologies. International relations scholars researching civilisations 
and world politics traverse histories of the present. They draw heavily from funds of social and political theory, but are not generative of theory as such. Domingues's sociology by comparison is quite theoretically 'agile', though enticingly incomplete when it comes to social imaginaries. His image of the civilisational imaginaries of modernity is fragmentary but serves as a reminder of the critical conditions of the present. Eisenstadt (2004) too supplied a prompt on the present in his analytic of the 'civilisation of modernity', as has, from another point of view, Roland Robertson (1987) with his sociological reflections at the interface of civilisational analysis and the globalisation paradigm. All three are timely supplements to the sharp historical sensibilities of civilisational analysis which sometimes leave scholars in the field focused on past horizons rather than present issues. Much remains ill-defined on this frontier, however. Eisenstadt's civilisation of modernity is the least systematised aspect of his sociological theory and Robertson's globalism has not been extensively debated in civilisational analysis. Domingues's alternative links globality with a budding notion of civilisational imaginaries. Yet this remains a promissory note about articulation of a different direction - civilisational imaginaries and globalities in the present - rather than a defined position. A great deal of potential exists for theoretical exchange between the fields of civilisational analysis and social imaginaries.

\section{Conclusion}

As noted, the social imaginaries field is heterogeneous. Indeed, as Calhoun et al. (2015) observe in this issue, the term 'social imaginaries' has been used in a way that can empty it of content. What is needed is a more systematic approach and comparative research program to build on and extend the key contributions to the field without flattening the ongoing conflict of interpretations. In other words, the social imaginaries field opens onto problematics which resists closure. We argued that social imaginaries has much to offer as a paradigm-in-the-making. This is especially the case when the theoretical frameworks underpinning it are not simply reduced to 'culture' or 'cultural meaning' but incorporate notions of social doing and power, as well. Its phenomenological and hermeneutic sources make it particularly helpful in developing an open (as opposed to closed) conception of culture as modes of being-in-the-world, that allow it to fruitfully engage with questions of the intercultural aspect of the human condition, be that at a concrete political level, or at the macro-level of multiple modernities and civilisational analysis. Social imaginaries presuppose society as a self-altering social world comprised of instituted and instituting aspects: it is thus well placed to elucidate movements towards social change, as well as recognising the existence of meaningful social practices. Finally, social imaginaries underlie notions of socio-political 
critique: for to be able to change social worlds, means that social worlds can be problematised and put into question.

\section{References}

Abbey, R 2006, 'Back to Baczko', European Journal of Social Theory, vol. 5, pp. 325336.

Adams, S 2011a, 'Arnason and Castoriadis' Unfinished Dialogue: Articulating the World', European Journal of Social Theory, vol. 14, no. 1, pp. 71-88.

Adams, S 2011b, Castoriadis' Ontology: Being and Creation, Fordham University Press, New York, NY.

Adams, S 2012, 'Castoriadis at the Limits of Autonomy? Ecological Worldhood and the Hermeneutic of Modernity', European Journal of Social Theory, vol. 15, no. 3, pp. 313- 329.

Adams, S 2014, 'The Commonality of the World and the Intercultural Element: Meaning, Culture, and Chora', in Ming Xie (ed) The Agon of Interpretations: Towards a Critical Intercultural Hermeneutics, University of Toronto Press, Toronto, Canada, pp. 65-82.

Anderson, B 1991 [1983], Imagined Communities: Reflections on the Origins and Spread of Nationalism, Verso, London.

Arendt, H 1992, Lectures on Kant's Political Philosophy, University of Chicago Press, Chicago, IL.

Aristotle, 1986, De Anima: On the Soul, trans. H Lawson-Tancred, Penguin, London.

Arnason, JP 1991, 'Modernity as Project and as Field of Tensions', in A Honneth \& $\mathrm{H}$ Joas (eds.), Communicative Action: Essays on Jürgen Habermas's 'The Theory of Communicative Action', MIT Press, Cambridge UK, pp. 181-212.

Arnason, JP 1993, 'Merleau-Ponty and Max Weber: An Unfinished Dialogue', Thesis Eleven, vol. 36, no. 1, pp. 82-98.

Arnason, JP 1994, 'Reason, Imagination, Interpretation' in G. Robinson \& J. Rundell (eds.), Rethinking Imagination: Culture and Creativity, Routledge, London, pp. 155-170.

Arnason, JP 2001, 'Capitalism in Context: Sources, Trajectories, and Alternatives', Thesis Eleven, vol. 66, pp. 99-125.

Arnason, JP 2002, 'The Multiplication of Modernity', in E. Ben-Rafael \& Y. Sternberg (eds.) Identity, Culture and Globalization, Brill, Leiden.

Arnason, JP 2003, Civilizations in Dispute: Historical Questions and Theoretical Traditions, Brill, Leiden.

Arnason, JP 2012, 'Castoriadis as a Civilizational Analyst: Sense and Non-Sense in Ancient Greece', European Journal of Social Theory vol. 15, no. 3, pp. 295-311.

Arnason, JP 2015, “The Imaginary Dimensions of Modernity', trans. S Adams, Social Imaginaries, vol.1, no. 1, pp. 135-149..

Baczko, B 1984, Les Imaginaires Sociaux, Payot, Paris. 
Bellah, RN \& Joas H (eds.) 2012, The Axial Age and its Consequences, The Belknap Press, Cambridge, MA.

Blokker, P 2010, Multiple Democracies in Europe. Political Culture in New Member States, Series: Democratization Studies, Routledge, London/New York.

Blokker, P 2014, 'The European Crisis and a Political Critique of Capitalism', special issue: 'Europe in Crisis', European Journal of Social Theory, vol. 17, no. 3, pp. 258-274.

Boltanski, L \& Chiapello, E 2005, The New Spirit of Capitalism, trans. G Elliott, Verso, London.

Breckman, W 2013, Adventures of the Symbolic, Columbia University Press, New York, NY.

Calhoun, C, Gaonkar D, Lee, B, Taylor, C, \& Warner, M 2015 'Modern Social Imaginaries: A Conversation', Social Imaginaries, vol. 1, no. 1, pp. 189-224.

Casey, ES 1993, Getting Back into Place: Toward a Renewed Understanding of the PlaceWorld, Indiana University Press, Bloomington, ID.

Castoriadis, C 1981, 'From Ecology to Autonomy', Thesis Eleven, vol. 3, no. 1, pp. 8-22.

Castoriadis, C 1987 [1975], The Imaginary Institution of Society, trans. K Blamey, MIT Press, Cambridge, MA.

Castoriadis, C 1991, Philosophy, Politics, Autonomy, ed. DA Curtis, Oxford University Press, New York/Oxford.

Castoriadis, C 1994, 'Radical Imagination and the Social Instituting Imaginary', in G Robinson \& J Rundell (eds.), Rethinking Imagination: Culture and Creativity, Routledge, London, pp. 136-154.

Castoriadis, C 1997, World in Fragments: Writings on Politics, Society, Psychoanalysis, and the Imagination, trans. DA Curtis (ed.), Stanford University Press, Stanford, CA.

Castoriadis, C 2007, Figures of the Thinkable, trans. H Arnold, Stanford University Press, Stanford, CA.

Castoriadis, C 2010, A Society Adrift: Interviews and Debates - 1974-1997, trans. H. Arnold, Fordham University Press, New York, NY.

Castoriadis, C 2015, 'The Imaginary as Such', trans. JP Arnason, Social Imaginaries, vol. 1 , no. 1 , pp. 59-69.

Clark, J 2002, 'Cornelius Castoriadis: Thinking about Political Theory', Capitalism, Socialism, Nature, vol. 13, no. 1, pp. 67-74.

Delanty, G 2010, 'Civilizational Analysis and Critical Theory', Thesis Eleven vol. 100, pp. 46-52.

Dewey, J 1962 [1934], A Common Faith, Yale University Press, New Haven, CT.

Domingues, JM 2012, Global Modernity, Development and Contemporary Civilization: Towards a Renewal of Critical Theory, Routledge, London.

Doyle, NJ 2003, 'Democracy as Socio-Cultural Project of Individual and Collective Sovereignty: Claude Lefort, Marcel Gauchet and the French Debate on Modern Autonomy', Thesis Eleven, vol. 75, no. 1, pp. 69-95. 
Doyle, NJ 2011, 'Re-Discovering Political Sovereignty: The Rebirth of French Political Philosophy', in G Delanty \& S Turner (eds.), The Handbook of Contemporary Social and Political Theory, Routledge, New York, NY.

Doyle, NJ 2013, 'Autonomy and Modern Liberal Democracy: From Castoriadis to Gauchet', European Journal of Social Theory, vol. 15, no. 3, pp. 1-18.

Durkheim, E 1976 [1912], The Elementary Forms of the Religious Life, $2^{\text {nd }}$ ed., Allen \& Unwin, London.

Eisenstadt, SN 1986, The Origins and Diversity of Axial Age Civilizations, State University of New York Press, Albany, NY.

Eisenstadt, SN 1999, Paradoxes of Democracy: Fragility, Continuity, and Change, Johns Hopkins University Press, Baltimore, MY.

Eisenstadt, SN 2000, 'Multiple Modernities', Daedalus vol. 129, pp. 1-30.

Eisenstadt, SN 2003, Comparative Civilizations and Multiple Modernities, Brill, Leiden.

Eisenstadt, SN 2004, 'The Civilizational Dimension of Modernity', in SA Arjomand \& E. Tiryakian (eds.), Rethinking Civilizational Analysis, Sage, London, pp. 4866.

Eisenstadt, SN \& Schluchter, W 1998, 'Introduction: Paths to Early Modernities - A Comparative View', Daedalus, vol. 127, no. 3, pp. 1-18.

Gaonkar, DP 1999, 'On Alternative Modernities', Public Culture, vol. 11, no. 1, pp.18.

Gaonkar, DP (ed.) 2000, Alternative Modernities, Duke University Press, Durham, NC.

Gauchet, M 1999, The Disenchantment of the World: A Political History of Religion, trans. O Burge, Princeton University Press, Princeton.

Gauchet, M 2015 'Democracy: From One Crisis to Another', trans. NJ Doyle, Social Imaginaries, vol. 1, no. 1, pp. 163-187.

Geertz, C 1977, The Interpretation of Cultures: Selected Essays, Basic Books, New York, NY.

Grant, J 2014, 'On the Critique of Political Imaginaries', European Journal of Political Theory, vol. 13, no. 4, pp. 408-426.

Hall, M \& Jackson, PT (eds.) 2007, Civilizational Identity: The Production and Reproduction of 'Civilizations' in International Relations, Palgrave Macmillan, New York, NY.

Heidegger, M 1969, The Essence of Reasons, Bilingual edition with Vom Wesen des Grundes, trans. Terrence Malick, Northwestern University Press, Evanston, IL.

Heidegger, M 1971, Poetry, Language, Thought, trans. A Hofstadter, Harper \& Row, New York, NY.

Heidegger, M 1977, Phänomenologische Interpretation von Kants Kritik der reinen Vernunft, (Gesamtausgabe: Band 25), F-W Herrmann (ed.), Vittorio Klostermann, Frankfurt am Main.

Heidegger, M 1985, Unterwegs zur Sprache. 1950-59, (Gesamtausgabe: Band 12), FW v. Herrmann (ed.), Vittorio Klostermann, Frankfurt am Main.

Heidegger, M 1990, Kant and the Problem of Metaphysics, trans. R Taft, Indiana University Press, Bloomington, IN. 
Heidegger, M 1991, Kant und das Problem der Metaphysik, (Gesamtausgabe: Band 3), FW v. Herrmann (ed.), Vittorio Klostermann, Frankfurt am Main.

Heidegger, M 1994, Beiträge zur Philosophie (Vom Ereignis), (Gesamtausgabe: Band 65), FW v. Herrmann (ed.), Vittorio Klostermann, Frankfurt am Main.

Heidegger, M 1997, Phenomenological interpretation of Kant's 'Critique of Pure Reason', trans. P Emad \& K Maly, Indiana University Press, Bloomington, IN.

Heidegger, M 1998, Pathmarks, ed. W McNeill, Cambridge University Press, Cambridge, UK.

Heidegger, M 1999, Contributions to Philosophy (From Enowning), trans. P Emad \& K Maly, Indiana University Press, Bloomington, IN.

Heidegger, M 2000, Vorträge und Aufsätze, (Gesamtausgabe: Band 7), FW v. Herrmann (ed.), Vittorio Klostermann, Frankfurt am Main.

Heidegger, M 2002, Off the Beaten Track, trans. J Young \& K Haynes (eds.), Cambridge University Press, Cambridge, UK.

Heidegger, M 2003, Holzwege, (Gesamtausgabe: Band 5), FW v. Herrmann (ed.), Vittorio Klostermann, Frankfurt am Main.

Howard, D 1988, 'Cornelius Castoriadis: Ontology as Political', The Marxian Legacy $2^{\text {nd }}$ ed., University of Minnesota Press, Minneapolis, pp. 321-336.

Jaspers, K 1953 [1929], The Origin and Goal of History, trans. M Bullock, Routledge \& Kegan Paul, London.

Joerges, C, Straith, B \& Wagner, P (eds.) 2005, The Economy as a Polity: The Political Constitution of Contemporary Capitalism, University College London, London.

Kant, I 1952, The Critique of Judgement, trans. JC Meredeth, Oxford University Press, Oxford.

Kant, I 1965, The Critique of Pure Reason, trans. NK Smith, St Martin's Press, Oxford.

Kant, I 1993, Kritik der reinen Vernunft, Felix Meiner Verlag, Hamburg.

Karagiannis, N \& Wagner, P 2012, 'Imagination and Tragic Democracy', Critical Horizons: A Journal of Philosophy \& Social Theory, vol. 13, no. 1, pp. 12-28.

Katzenstein, PJ (ed.) 2010, Civilizations in World Politics. Plural and Pluralist Perspectives, Routledge, London and New York, NY.

Kaya, I 2004, Social Theory and Later Modernities: The Turkish Experience, Liverpool University Press, Liverpool.

Kearney, R 1988, The Wake of the Imagination, Routledge, London.

Kearney, R \& Taylor, C 2007, 'On Social Imaginaries', in P Gratton \& JP Manoussakis (eds.), Traversing the Imaginary: Richard Kearney and the Postmodern Challenge, Northwestern University Press, Evanston, IL.

Krummel, J 2007, 'Representation and Poiesis: The Imagination in the Later Heidegger,' Philosophy Today, vol. 51, no. 3, pp. 261-276.

Krummel, J 2014, 'World, Nothing, and Globalization in Nishida and Nancy' in L Kalmanson \& JM Shields (eds.), Buddhist Responses to Globalization, Lexington Books, Lanham MD.

Lacan, J 1977, Écrits: A Selection, trans. A Sheridan, Norton, New York, NY.

Lamont, M \& Laurent, T 2000, Rethinking Comparative Cultural Sociology: Repertoires of Evaluation, Cambridge University Press, Cambridge, UK.

Lee, B \& Gaonkar, DP, 2002, 'New Imaginaries', Public Culture, vol.14, no.1. 
Lefort, C 1978 [1953], 'Société "sans histoire” et historicité, in Les Formes de l'histoire, Gallimard, Paris.

Lefort, C 1986, The Political Forms of Modern Society: Bureaucracy, Democracy, Totalitarianism, ed. JB Thompson, MIT Press, Cambridge, MA.

Lefort, C 1988, Democracy and Political Theory, trans. D Macey, Polity Press in association with Basil Blackwell, Cambridge/Oxford, UK.

Malpas, J 1999, Place and Experience: A Philosophical Topography, Cambridge University Press, Cambridge, UK.

Mannheim, K 1954 [1929], Ideology and Utopia: An Introduction to the Sociology of Knowledge, Routledge \& Kegan Paul, London.

Michel, J 2013, Ricoeur et ses Contemporains. Bourdieu, Derrida, Deleuze, Foucault, Castoriadis, Presses Universitaires de France, Paris.

Miki, K 1967a, Kösōryoku no ronri [The Logic of the Imagination], in Miki K zenshü dai hachi [Collected Works of Miki Kiyoshi, vol. 8], Iwanami, Tokyo.

Miki, K 1967b, Bungakuron kō [Manuscripts on Literary Theory] in Miki K zenshū dai jüichi [Collected works of Miki Kiyoshi, vol. 11], Iwanami, Tokyo.

Nakamura, H 1983, Kyōtsūkankakuron [On Common Sense], Iwanami, Tokyo.

Pieterse, JN 2012, 'Global Rebalancing: Crisis and the East-South Turn', in J Kim \& JN Pieterse (eds.), Globalization and Development in East Asia, Taylor and Francis, Hoboken, NJ, pp. 36-60.

Ricoeur, P 1991a, 'The Creativity of Language', in MJ Valdes (ed.), A Ricoeur Reader: Reflection and Imagination, Toronto University Press, Toronto.

Ricoeur, P 1991b, 'Myth as the Bearer of Possible Worlds' in MJ Valdes (ed.), A Ricoeur Reader: Reflection and Imagination, Toronto University Press, Toronto.

Ricoeur, P 1976, 'Ideology, Utopia, Faith' in The Centre for Hermeneutical Studies, vol. 17, pp. 21-28.

Ricoeur, P 1986, Lectures on Ideology and Utopia, G Taylor (ed.), Chicago University Press, Chicago, IL.

Ricoeur, P 1994, 'Imagination in Discourse and Action,' in G Robinson \& J Rundell (eds.), Rethinking imagination: Culture and Creativity, Routledge, London, pp. 118-135.

Roberts, D 1994, 'Sublime Theories: Reason and Imagination in Modernity', in G Robinson \& J Rundell (eds.), Rethinking imagination: Culture and Creativity, Routledge, London, pp. 171-183.

Robertson, R 1987, 'Globalization Theory and Civilizational Analysis', Comparative Civilizations Review, vol.17, Fall, pp. 20-30.

Rosanvallon, P 2009, 'Democratic universalism as a historical problem', Constellations, vol. 16, no. 4, pp. 539-549.

Rosanvallon, P 1979, Le Capitalisme Utopique: Critique de l'idéologie Économique, Gallimard, Paris. $2^{\text {nd }}$ ed, 1999, as Capitalisme Utopique. Histoire de l'idée de Marché.

Rundell, J 1994, 'Creativity and Judgment: Kant on Reason and Imagination', in G Robinson \& J Rundell (eds.), Rethinking imagination: Culture and Creativity, Routledge, London, pp. 87-116.

Rundell, J 2012, 'Modernity, Humans and Animals - Tensions in the Field of the Technical- Industrial Imaginary', New Formations, vol. 76, pp. 8-20. 
Sallis, J 1990, Echoes: After Heidegger, Indiana University Press, Bloomington, IN.

Sallis, J 2000, Force of Imagination: The Sense of the Elemental, Indiana University Press, Bloomington, IN.

Sartre, JP 1962, The Imagination: A Psychological Critique, University of Michigan Press, Ann Arbour, MI.

Sartre, JP 1966 [1940], L'imaginare: Psychologie Phenomenologique de L'imagination, Gallimard, Paris.

Smith, JCA 2012, 'Revolutionary Doctrines and Political Imaginaries: American Modernities in the Republican Age', Critical Horizons, vol.13, no. 1, pp. 52-73.

Smith, JCA 2014a, 'Atlantic Capitalism, American Economic Cultures', in S Arjomand (ed.), Social Theory and Regional Studies in the Global Age, State University of New York Press, Albany, NY, pp. 339-359.

Smith, JCA 2014b, 'Contexts of Capitalism: From the 'Unlimited Extension of "Rational Mastery" to Civilizational Varieties of Accumulation and Economic Imagination', in V Karalis (ed.), Cornelius Castoriadis and Radical Democracy, Brill, Leiden, pp. 158- 176.

Smith, K 2010, Meaning, Subjectivity and Society: Making Sense of Modernity, Brill, Leiden.

Soper, K 2009, 'Unnatural times? The Social Imaginary and the Future of Nature', The Sociological Review, vol. 57, pp. 222-235.

Steele, M 2003, 'Ricoeur versus Taylor on Language and Narrative', Metaphilosophy, vol. 34, no. 4, pp. 425-446.

Straume, I \& Humphrey, JF (eds.) 2010, Depoliticization: The Political Imaginary of Global Capitalism, Nordic Summer University Press, Ahrus.

Strauss, C 2006, 'The Imaginary', Anthropological Theory, vol. 6, no. 3, pp. 322-344

Taylor, C 1985, Philosophical Papers, Cambridge University Press, Cambridge, MA.

Taylor, C 1989, Sources of the Self: The Making of Modern Identity, Harvard University Press, Cambridge, MA.

Taylor, C 1995, 'Heidegger, Language, Ecology', in Philosophical Arguments, Harvard University Press, Cambridge, MA, pp. 100-126.

Taylor, C 1999, 'Two Theories of Modernity', Public Culture, vol. 11, no. 1, pp. 153174.

Taylor, C 2002, 'Modern Social Imaginaries', in Lee B \& Gaonkar DP, special issue: 'New Imaginaries', Public Culture, vol. 14, no.1, pp. 91-124.

Taylor, C 2004, Modern Social Imaginaries, Duke University Press, Durham, NC.

Taylor, C 2007, A Secular Age, Harvard University Press, Cambridge, MA.

Taylor, C 2012, 'What was the Axial Revolution?', in RN Bellah \& H Joas (eds.), The Axial Age and its Consequences, The Belknap Press, Cambridge, MA, pp. 30-46.

Therborn, G 2003, 'Entangled Modernities', European Journal of Social Theory, vol. 6, no. 3, pp. 293-305.

Thompson, JB 1982, 'Ideology and the Social Imaginary: An Appraisal of Castoriadis and Lefort', Theory and Society, vol. 11, no. 5, pp.659-681.

Wagner, P 2012, Modernity: Understanding the Present, Polity Press, Cambridge UK.

Wagner, P 2015, 'Interpreting the Present - A Research Programme', Social Imaginaries, vol. 1, no. 1, pp. 105-129. 
Ward, G 2005, Cultural Transformation and Religious Practice, Cambridge University Press, Cambridge UK.

Waxman, W 1991, Kant's Model of the Mind: A New Interpretation of Transcendental Idealism, Oxford University Press, Oxford.

\section{Acknowledgement}

We would like to thank Erin Carlisle and George Sarantoulias for their tireless help in preparing the manuscript for publication.

\section{Author Biographies}

Suzi Adams is Senior Lecturer in Sociology at Flinders University (Adelaide), and External Fellow at the Central European Institute of Philosophy, Charles University (Prague). Her most recent essays include 'The Commonality of the World and the Intercultural Element: Meaning, Culture, and Chora', in Ming Xie (ed.), The Agon of Interpretations: Towards a Critical Intercultural Hermeneutics (2014); 'Merleau-Ponty, Castoriadis and Nature', In K Novotný, P Rodrigo, J Slatman \& S Stoller (eds.), Corporeity and Affectivity: Dedicated to Maurice Merleau-Ponty. (2014); 'Castoriadis, Arnason and the Phenomenological Question of the World'. In IS Straume \& G Baruchello (eds.), Creation, Rationality and Autonomy: Essays on Cornelius Castoriadis (2013); Castoriadis at the Limits of Autonomy? Ecological Worldhood and the Hermeneutic of Modernity'. European Journal of Social Theory, 2012, vol. 15, no. 3, and 'Castoriadis and the Non-Subjective Field: Social Doing, Instituting Society and Political Imaginaries', Critical Horizons, 2012, vol. 13, no. 1, pp. 29-51. Recent books include Castoriadis's Ontology: Being and Creation (2011) and Cornelius Castoriadis: Key Concepts (2014). Address: Sociology, Flinders University, GPO Box 2100, Adelaide, SA, 5001, Australia. Email: Suzi.adams@flinders.edu.au

Paul Blokker, PhD. (European University Institute, Florence) is Associate Professor in Sociology at the Institute of Sociological Studies, Charles University, Prague. His recent publications include: 'The European Crisis and a Political Critique of Capitalism', European Journal of Social Theory, 2014, vol. 17, no. 3; 'Boltanski and Democratic Theory: Fragility and Critique as Democracy's Essence', Thesis Eleven, 2014, vol. 10, no. 23; New Democracies in Crisis? A Comparative Constitutional Study of the Czech Republic, Hungary, Poland, Romania and Slovakia, Routledge Advances in European Politics (2013); guest editor of special issue on 'Pragmatic Sociology: Theory, Critique, and Application', European Journal of Social Theory, 2011, vol. 14, no. 3; Multiple Democracies in Europe. Political Culture in New Member States, Democratization Series, London/New York: Routledge (2010). Address: Faculty of Social Sciences, Institute of Sociological Studies, Charles University, U Kř́žze 8, 15800 Prague 5 - Jinonice. E-mail: paulus.Blokker@fsv.cuni.cz 
Natalie J. Doyle is Senior Lecturer in French Studies and European studies at Monash University and deputy director of the Monash European and EU Centre. Her most recent publications include: 'The De-Politicising Logic of European Economic Integration' in NJ Doyle \& L Sebesta (eds.), Regional Integration and Modernity. Cross Atlantic Perspectives, Lanham: Lexington Books, 2014, pp. 213-263; 'Governance and Democratic Legitimacy: the European Union's Crisis of De-Politicization' in Crisis and Democracy in the Twenty-First Century: Democratising Governance, 2014, B Isakhan \& S Slaughter (eds.), Palgrave MacMillan, New York, NY; 'Islam, Depoliticization and the European Crisis of Democratic Legitimacy', Politics, Religion \& Ideology, 2013, vol. 14, no. 2, pp. 265-283; 'Autonomy and Modern Liberal Democracy: From Castoriadis to Gauchet', European Journal of Social Theory, 2013, vol. 15, no. 3, pp. 331-347. She is currently working on a book to be published by Lexington Books, 'European Democracy, De-Politicization and Imaginary Constructs of Islam: the Loss of Common Purpose'. Address: School of LLCL, Faculty of Arts, Monash University, Clayton, Vic 3800 Australia. Email: Natalie.Doyle@monash.edu

John W.M. Krummel is Associate Professor in the Dept. of Religious Studies at Hobart and William Smith Colleges in Geneva, NY. He has a Ph.D. in Philosophy from the New School for Social Research and a Ph.D. in Religion from Temple University. He is author of Nishida Kitarös Chiasmatic Chorology: Place of Dialectic, Dialectic of Place (Indiana University Press, 2015 forthcoming). His writings on topics such as Heidegger, Nishida, Schürmann, and Buddhist philosophy, among others, have appeared in a variety of philosophy journals and books. He is also the co-translator of, and author of the introduction for, Place and Dialectic: Two Essays by Nishida Kitarō (Oxford University Press, 2011), and has translated other works from Japanese and German into English. In addition to being an editor for Social Imaginaries, he is also the Assistant Editor of The Journal of Japanese Philosophy published by SUNY Press. Address: Religious Studies, Demarest Hall, 300 Pulteney St. Hobart and William Smith Colleges Geneva, NY 14456-3382, U.S.A. Email: Krummel@hws.edu

Jeremy Smith is a Senior Lecturer in the Faculty of Education and Arts at Federation University (Ballarat), and Visiting Fellow at the Center for Studies in Religion and Society, University of Victoria (Victoria, Canada). He has published in European Journal of Social Theory, Journal of Intercultural Studies, Political Power and Social Theory, Critical Horizons and Atlantic Studies on Europe, the Americas and Japan and key theorists in civilizational sociology. He is author of Europe and the Americas: State Formation, Capitalism and Civilizations in Atlantic Modernity (Brill, 2006), has co-edited (with Danielle Petherbridge, John Rundell, Jan Bryant and John Hewitt) Contemporary Perspectives in Social and Critical Philosophy (Brill, 2004), and is coeditor (with Alice Mills) of Utter Silence: Voicing the Unspeakable (Peter Lang, 2001). He has recently authored Debating Civilizations: Interrogating Civilizational Analysis in the Global Age, (Bloomsbury, forthcoming). Address: Faculty of Education and Arts, Federation University Australia, Mt Helen Campus, PO Box 663 Ballarat VIC 3353, Australia Email: Jeremy.smith@federation.edu.au 


\section{Notes}

1 The 'First Attempt' is taken from the sub-title of his essay published first in Socialisme ou Barbarie and then, with very minor addenda, in the1964-65 section of The Imaginary Institution of Society, as 'The Imaginary and the Institution: A First Approach'.

2 Ricoeur's seminars on the philosophy of the imagination are currently in preparation for publication in both French and English (Edited by George Taylor).

3 The Castoriadis/Ricoeur dialogue is currently being edited by Olivier Fressard and Johann Michel for publication in a collection of essays commissioned by the EHESS. Publication is expected in 2015.

4 Castoriadis does not ignore the phenomenon of power but it is treated unsystematically in his thought.

5 This disagreement is at its most explicit in their Radio France (Culture) discussion

6 See Kearney 1988, p. 155-156.

7 Numbers followed by $A$ in parentheses refer to pagination from the German original of the first edition Kant's Critique of Pure Reason and those followed by $B$ refer to pagination from the second edition (both in Kant 1965 and 1993).

8 Wayne Waxman, for example, reads Kantian imagination as a non-discursive form of spontaneity in contrast to the understanding that is the discursive form of spontaneity. See Waxman 1991, pp. 285-86.

9 Kant calls this creative act of the productive imagination in the schematism, 'figurative synthesis' (1965/1993, p. B151).

10 As noticeable in the functioning of the symbol (e.g., beauty as the symbol for morality) in the aesthetic realm. See Kant’s Critique of Judgment (1952), \$59.

11 For example, Johann P. Arnason, John Rundell, and Cornelius Castoriadis's essays in G Robinson \& J Rundell (1994).

12 The claim that Heidegger was totally silent on the subject of the imagination after his Kant-reading of the 1920s (Castoriadis 1994, p. 136) is plainly not true. See Krummel (2007).

13 It must be pointed out that Castoriadis and Lefort offer different assessments of the relationship between the economic and political dimensions of modernity which translates into a different interpretation of democratic autonomy and of the historical significance of the Greek model. Castoriadis established a stark dichotomy between the imaginary of limitless (pseudo)rational mastery underpinning and the imaginary of democratic autonomy defined by an acceptance of historical indeterminacy. By contrast, Lefort's work stressed the role played by a new relationship to the natural world (encapsulating the notion of work) in the formation of a modern historical perspective predicated on a new understanding of state power (see below, in main text) essentially distinct from the historicity evident in Greek democracy (Lefort 1978 [1953]; 'The Permanence of the theologico-political?' in Lefort 1988). The idea that the economic perspective and the notion of market played a role in the historical genesis of modern liberal democracy was developed by Lefort's erstwhile doctoral student Pierre Rosanvallon in Le Capitalisme Utopique. Critique de l'idéologie Économique (1999 
[1979]). It also inspired the theory of modernity put forward by Marcel Gauchet (another former student of Lefort) in The Disenchantment of the World (1999). In recent writings (see 'Democracy: From One Crisis to Another' in this issue, 2015) Gauchet has presented a critique of the oligarchic evolution of contemporary democracy which evokes one of the strong themes of Castoriadis' work. Whilst Gauchet's analysis also rejects Castoriadis's opposition between capitalism and democracy, like Lefort's work before it and its understanding of ideology, it still remains indebted to Castoriadis's exploration of the roots of human institutions in imaginary constellations of meaning (Doyle 2013). 